\title{
MICROSCOPIC STRUCTURE OF THE EGG CAPSULE OF ATLANTORAJA CYCLOPHORA (ELASMOBRANCHII: RAJIDAE: ARHYNCHOBATINAE)
}

\author{
María Cristina Oddone ${ }^{1}$
}

Biota Neotropica v3 (n1) - http://www.biotaneotropica.org.br/v5n2/pt/abstract?short-communication+bn01105022005

Date Received : 11/15/2004.

Revised : 04/10/2005.

Accepted : 07/01/2005.

${ }^{1}$ Fundação Universidade Federal do Rio Grande, Dpto de Oceanografia, Laboratório de Elasmobrânquios e Aves

Marinhas, Caixa Postal 474, CEP 96201-900, Rio Grande-RS, Brazil (www.furg.br).

Present address: Universidade Estadual Paulista, Instituto de Biociências, Departamento de Ecología. Campus Rio Claro, Av. 24-A 1515-CP 199, 13506-900. Rio Claro, São Paulo, Brazil. Tel: (+55-19) 3526-4225; Fax: (+55-19)3526-4226

(www.rc.unesp.br). E-mail: mcoddone@rc.unesp.br

\begin{abstract}
The microscopic structure of the egg capsules of Atlantoraja cyclophora, a species endemic to the Atlantic region of South America, is presented in this paper. In a transverse section, the dorsal face of the egg case is $70 \mu$ in width, and is subdivided into four layers. Ventrally, the egg capsule wall is $60 \mu$ wide and composed of three layers. Both faces are covered by prickles which render the egg capsule surface striated to the naked eye.
\end{abstract}

Key words: rajoids, egg capsules , Atlantoraja cyclophora, oviparity.

\section{Resumo}

A estrutura microscópica da cápsula ovífera de Atlantoraja cyclophora, endêmica na região sul-americana do Atlântico, é apresentada neste artigo. Em seção transversal, a face dorsal da cápsula ovígera tem uma largura de 70 $\mapsto$, e está subdividida em quatro camadas. Ventralmente, a parede da cápsula ovígera tem uma largura de $60 \Perp$ e é conformada por três camadas. Ambas as faces acham-se cobertas por protuberâncias, que fazem com que a superfície da cápsula seja estriada ao olho nu.

Palavras-chave: rajideos, cápsulas ovígeras, Atlantoraja cyclophora, oviparidade.

http://www.biotaneotropica.org.br 


\section{Introduction}

Skates (Rajidae) are unique among the Rajiformes in being oviparous. Females are internally fertilised and secrete a capsule around the fertilised egg, consisting of a multilaminate, proteinaceous matrix, which is subsequently shed in the environment. The females select oviposition sites and egg capsules are attached to marine debris of diverse origin in advantageous locations, which may be visited yearly by females (Hamlett \& Koob, 1999). Egg capsules are structurally variable and may be species-specific but cannot be identified until they are first correlated with particular species (obtained within pregnant females of a species). They protect the embryo throughout its development, so that they may withstand prolonged exposure to the corrosive action of sea water and predation (Hamlett \& Koob, 1999).

In the western South Atlantic, skate egg capsules have been described for Sympterygia, Atlantoraja and Psammobatis (Oddone \& Vooren 2002; Braccini \& Chiaramonte 2002; Mabragaña et al. 2002; Oddone \& Vooren 2004; Oddone et al. 2004), even though for Sympterygia bonapartii (Mabragaña et al. 2002) and Psammobatis extenta (Braccini \& Chiaramonte 2002) the descriptions may be somewhat rudimentary and incomplete. However, all these descriptions have dealt with the gross morphology of the egg capsules and not with its microscopic structure.

Ishiyama (1958) demonstrated that the microscopic structure of Japanese skates' egg capsules (genera Dipturus, Okamejei, Bathyraja and Rhinoraja) is systematically informative. However, there have been no further studies on this topic. The purpose of this study is to present the microscopic structure of the egg capsule of Atlantoraja cyclophora (Regan 1903), a species endemic to the Atlantic region of South America.

\section{Materials \& Methods}

Egg capsules of Atlantoraja cyclophora were extracted from gravid females caught between Chuí and Cape Santa Marta Grande (South Brazil) between the latitudes 3040’S and $34^{\circ} 30^{\prime}$ 'S, in depths between 100 and $300 \mathrm{~m}$, on board of the R/V Atlântico Sul. Egg capsules were fixed with formalin 4\% for 12 hours, then preserved with ethanol 70\% and deposited in the Laboratório de Elasmobrânquios e Aves Marinhas (FURG - Fundação Universidade Federal do Rio Grande).

Transverse sections of approximately $0.5 \mathrm{~mm}$ in width where manually done on the egg capsules (Figure 1) by using a scalpel, on both ventral and dorsal faces, following Ishiyama (1958). The sections were placed on histological slides temporarily covered with distilled water for observation, and then sketched using a stereomicroscope Jenamed II, at the Laboratório de Morfologia Funcional from FURG.

\section{Results \& Discussion}

To the naked eye, the egg capsule of $A$. cyclophora is dorsally and ventrally longitudinally striated, with this striation being evidently more pronounced dorsally than ventrally (Oddone et al. 2004). Microscopically, striations on the dorsal face resemble a regular prickly surface. Each prickle measures $30 \mu$ in height and width, and is uniformly distributed and separated approximately $90 \mu$ from one another (Figure 2), presenting a lighter lumen.

The dorsal face of the egg case is $70 \mu$ in width and consisted of four layers, distinctive in colour and texture. The layers are: i) the dorsal external layer; dark brown in colour, characterised by its homogeneous aspect, and $18 \mu$ wide; ii) the dorsal first middle layer; shiny yellow and markedly laminar, and $24 \mu$ wide; iii) the dorsal second middle layer; which is subdivided in two layers, the most external being light brown and the internal yellow, and $20 \mu$ wide (both sub-layers); and iv) the dorsal interior layer; also subdivided in two layers, the most external being dark brown continued by a yellow and laminar layer, and $8 \mu$ wide (both sub-layers, Figure 2).

The ventral surface possesses randomly arranged prickles averaging $18 \mu$ in width and $10 \mu$ in height, and separated by about $96 \mu$ from adjacent prickles. The same pattern of a light, uncoloured lumen is present, which could suggest the presence of an empty duct. In transverse section, the ventral face of the egg capsule is $60 \mu$ in width, and comprises three well-delimited layers: i) the ventral external layer, darkbrown, and $24 \mu$ wide; ii) the ventral middle layer, light brown and laminar and $=18 \mu$ wide; iii) the ventral interior layer, reddish-brown, and $18 \mu$ wide (Figure 2,3).

Ishiyama (1958) observed that the main portion of the rajoid egg capsule is made of two or more kinds of tissue, which he called an inner, "pulpy layer" which corresponds with the central, light coloured layer on both faces of A. cyclophora, and an outer layer (Ishiyama 1950, apud Ishiyama 1958). Ishiyama (1958) failed in not specifying whether his observations had been done using the ventral or the dorsal wall of the egg capsule. Therefore, comparisons between our study and his are not warranted. Microscopic structures described as "tubercles" by this author would correspond with the prickles described in the present study for A. cyclophora (i.e., the striations of the egg capsules). Also the dimensions of such "tubercles" observed by Ishiyama remain unknown. He distinguished the egg capsules into two types: the "northern" forms (Bathyraja and Rhinoraja), characterised by a much thickened outer layer with either tubercles or prickles on the surface of a horny, brown substance, and a rather thin inner layer without a noticeable difference in histological structure among different species. Ishiyama attributed the latter form to species belonging to cold-water areas. On the other hand, in the "southern" members (Dipturus and Okamejei), a specialisation was found not only in the outer layer but in the inner one as well. 


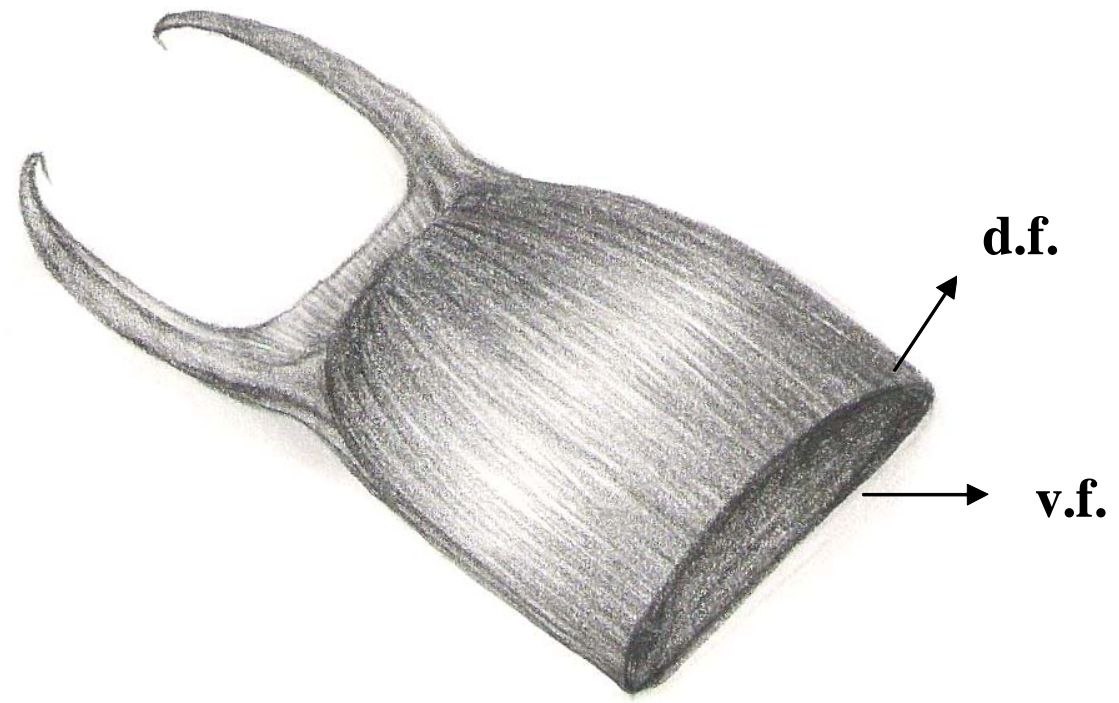

Figure 1. Transverse section of the egg capsule of Atlantoraja cyclophora (anterior end). d.f.=dorsal face; v.f.=ventral face.

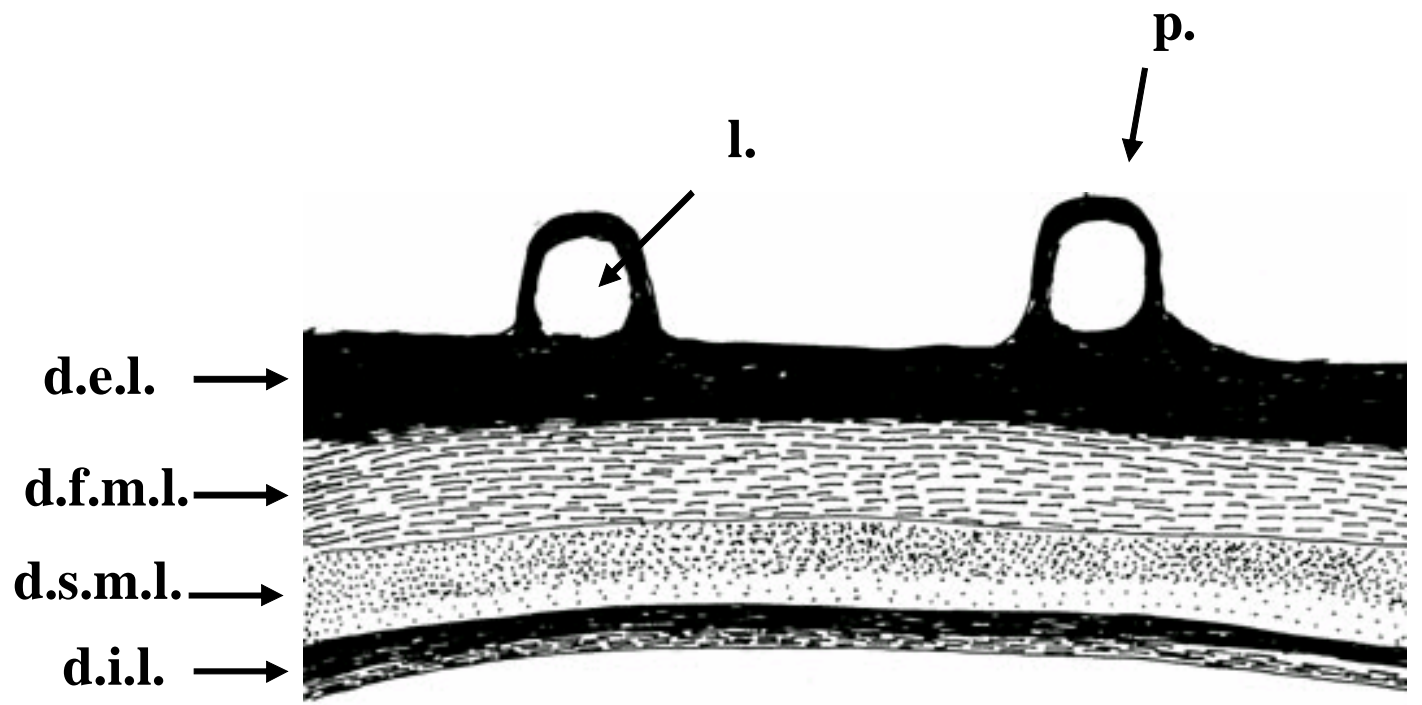

Figure 2. Transverse section of the dorsal face of the egg capsule of Atlantoraja cyclophora (200X); $p=$ prickles; l.=lumen; d.e.l.=dorsal external layer; d.f.m.l. =dorsal first middle layer; d.s.m.l.=dorsal second middle layer; d.i.l. $=$ dorsal interior layer.

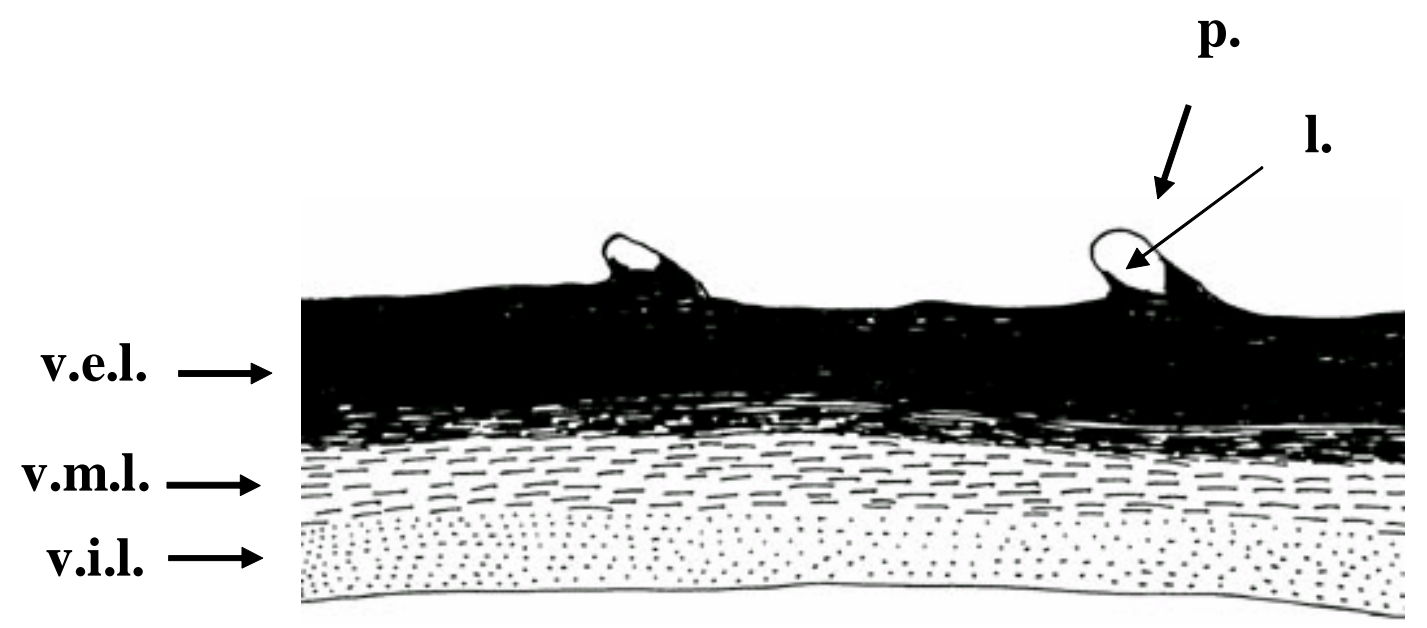

Figure 3. Transverse section of the ventral face of the egg capsule of Atlantoraja cyclophora (200X); $p=$ prickles; l.=lumen; v.e.l.= ventral external layer; v.m.l. $=$ ventral middle layer; v.i.l. $=$ ventral interior layer

http://www.biotaneotropica.org.br 
In Southern Brazil, specimens of A. cyclophora are found at up to $300 \mathrm{~m}$ in depth and temperatures ranging between $10.0^{\circ} \mathrm{C}$ and $17.6^{\circ} \mathrm{C}$ (Vooren 1997, Oddone \& Vooren 2004). The pronounced striations in the egg capsule surface could serve as protection for the embryo throughout development, as it has to withstand a more prolonged exposure in colder waters than species that inhabit shallower waters, which are subjected to higher temperatures. Egg capsules of Sympterygia acuta and Rioraja agassizi, for instance, have smooth surfaces (C.M. Vooren, unpublished data) and these are species that complete their life cycle on the shallower areas of the continental shelf, up to $40-50 \mathrm{~m}$ in depth (Vooren 1997).

In Scylorhinus canicula the most internal part of the egg capsule is formed by piled laminae (Knight \& Hunt, 1976) which would likewise correspond with the pulpy layer described by Ishiyama (1958). Krishnan (1959) described for the oviparous shark Chiloscyllium griseum the so-called "pulpy layer" as rather uncoloured too (in relation to the most external layers), and being characterised by horizontal lamination. Knight \& Hunt (1976), proposed a $45^{\circ}$ orientation between both lamina in vertical longitudinal sections for oviparous dogfishes. In both faces of A. cyclophora, the central, pulpy layer, was differentiated into two layers. This could reflect the presence of a single protein component but with fibres disposed in different directions.

\section{Acknowledgements}

Dr. Carolus Maria Vooren (FURG) oriented the M.Sc. thesis from which part of the present manuscript was based on. Biol. Roseane P. Bispo Bernardini (Universidade Metodista de Piracicaba) kindly draw Figure 1. Biol. Renato Zacarias Silva (FURG) collaborated with valuable suggestions and assistance in histology. Biol. Pablo Trujillo (University of British Columbia, Canada) kindly revised and corrected the English grammar.

\section{References}

BRACCINI, J.M. \& CHIARAMONTE, G.E. 2002. Reproductive Biology of Psammobatis extenta. Jour. Fish Biol. 61: 272-288.

HAMLETT, WC. \& KOOB, T.J. 1999. Female reproductive system, pp 398-443. In: Sharks, Skates and Rays: Biology of Elasmobranch Fishes, Ed. W. C. Hamlett, The Johns Hopkins University Press, Baltimore, Maryland.

ISHIYAMA, R. 1950. Studies on the rays and skates belonging to the family Rajidae, found in Japan and adjacent regions. 1. Egg-capsule of ten species. Jap. J. Ichthyol. 1:30-36.

ISHIYAMA, R. 1958. Observations on the eggs-capsules of skates of the family Rajidae, found in Japan and its adjacent waters. Bull. Mus. Comp. Zool. Harvard Col.. 18(1): 1-24.
KNIGHT, D.P. \& HUNT, S.H. 1976. Fine structure of the dogfish egg case: a unique collagenous material. Tis. \& Cell. 9768(1): 183-193.

KRISHNAN, G. 1959. Histochemical studies on the nature and formation of egg capsule of the shark Chiloscyllium griseum. Biol. Bull. 117: 298-307.

MABRAGAÑA, E., LUCIFORA, L.O \& MASSA, A.M. 2002. The reproductive biology and abundance of Sympterygia bonapartii endemic to the south-west Atlantic. Jour. Fish Biol. 60: 951-967.

ODDONE, M.C, MARÇAL, A.S. \& VOOREN, C.M. 2004. Egg capsules of Atlantoraja cyclophora (Regan, 1903) and A. platana (Günther, 1880) (Pisces, Elasmobranchii, Rajidae). Zootaxa. 426: 1-4.

ODDONE, M.C. \& VOOREN, C.M. 2002. Egg-cases and size hatching Sympterygia acuta in the south-western Atlantic. Jour. Fish. Biol. 61: 858-861.

ODDONE, MC \& VOOREN, CM. 2004. Distribution and abundance of Atlantoraja cyclophora (Regan 1903) (Elasmobranchii, Rajidae) with regard to salinity, temperature and depth in southern Brazil, south-western Atlantic. Neot. Ichthyol.. 2(3): 137-143.

VOOREN, C.M. 1997. Demersal Elsamobranchs, pp. 141-146. In: Environment and Biota of the Patos Lagoon Estuary. Seeliger, U., Odebrecht, C. \& Castello, J.P. (Eds). Subtropical convergence environments: the coast and sea in the south western Atlantic. Berlim. Springer-Verlag, 308 p.

Title: Microscopic structure of the egg capsule of Atlantoraja cyclophora (Elasmobranchii: Rajidae: Arhynchobatinae).

\section{Author: María Cristina Oddone}

Biota Neotropica, Vol. 5 ( number 2): 2005

http://www.biotaneotropica.org.br/v5n2/pt/ abstract?short-communication+bn01105022005

Date Received : 11/15/2004.

Revised : 04/10/2005.

Accepted : 07/01/2005.

ISSN 1676-0611 